\title{
Capital, Operational Efficiency And Credit Risk In The Banking Intermediation
} (Study On Regional Development Bank All Over Indonesia In 2014 )

\author{
Herry Achmad Buchory \\ EKUITAS Economics College, \\ J1. PHH. Mustopa No. 31 Bandung 40124, Indonesia \\ Email :achmad_buchory@yahoo.com
}

\begin{abstract}
Regional Development Bank in Indonesia was established to accelerate the growth of the economy. But in reality the contribution of BPD to Gross Regional Domestic Product in $\mathbf{2 0 1 4}$ was still relatively small. The aim of this study was to analyze the factors that affect the banking intermediation includecapital, operational efficiency, and credit risk. The methods used are descriptive and verificative, with secondary data from financial statements all over 26 Indonesian Regional Development Banks as a research object's units. Data analysis technique is the multiple linear regression, hypothesis testing while using $t$ - test to examine the effect of partial variables and test $-F$ to examine the effect of variables simultaneously with a significance level of $5 \%$.Based on the results it is concluded that partial CARand OEOIhave positive and significant effects on LDR. While the NPLshas negativeand significant effect on LDR. Simultaneously CAR, OEOI and NPLs significant effect on the LDR with level of influence of $12.8 \%$ and the remaining influenced by other factors not examined in this study
\end{abstract}

Keywords : Capital Adequacy Ratio; CAR;Loan to Deposit Ratio; LDR;Non-Performing Loans; NPLs; Operating Expense to Operating Income Ratio; OEOI;

\section{INTRODUCTION}

Bankas the depository financial institution holds a very important role in the economy of a country. Bank facilitates the interests of savers with borrowers through products and financial services it offers. It can not be denied that the role of banks which can be used as a tool in setting monetary policy is also the primary source of credit to most small businesses and individuals, which will ultimately affect the economic growth of a country (Koch, 2000; Buchory, 2006).The role that financial institutions have played in financial intermediation and growth, namely to mobilize savings and allocate them to the most productive and growth-promoting activities (Mahran,2012).

Intermediation function performed by banks through the purchase of surplus funds from economic units (business sector, government and individual / household) to be distributed to deficit economic units (Hempel et al., 1994). In other words, a financial intermediation is the diversion of funds activities from savers (ultimate lenders) to the borrower (the ultimate of borrowers). Implementation of financial intermediation in banking can be seen from the bank's ability to transform the savings are received primarily from household economic units into credit or loans for companies and other parties to make investments in buildings, equipment and other capital goods (Rose, 2002).
In the context of Indonesia's economy, the dominant role of banks remainsas compared to other financial institutions. This can be seen from the market share asset indicators of financial industry through the month of December 2014. Banks still dominate the market share, which is equal to $83.10 \%$, followed by $11.43 \%$ for insurance companies, $6.45 \%$ for finance companies, $2.75 \%$ for pension funds, $1.70 \%$ for social insurance companies, $0.07 \%$ for others finance services. (Financial Service Authority, Republic of Indonesia and Bank Indonesia, 2014)

Regional Development Bank (BPD) in Indonesia was established with the intent to provide funding for the implementation of local development efforts in the framework of National Development (Law no. 13 1962). Later in the decree of Ministry of Internal Affair No. 62 in 1999, affirmed that the principal task of developing the economy and the BPD is moving regional development, while the function is:

(1) Promoting the creation of the level of economic growth and regional development in order to improve the standard of living of the people

(2) The holder or a regional treasury and financial management areas

(3) One source of revenue.

However up to this time, in carrying out its duties and functions of the BPD still faces several problems, among which: limited capital; brand awareness community to BPD is still very low; quality of service does not meet the expectations of society ; quality and human resources competencies have not been standardized; innovation and product development is still limited; networks office services is still limited ; not optimal strategic partnership; structure of public funding is relatively low ; composition of the productive loan portfolio is relatively low, and not consolidate information technology (Eko Budiwiyono, 2012).

As one of the commercial banks, BPD plays a very important role in the economy, especially the regional economy. The role is mainly seen how wide BPD can apply intermediary function. One commonly used indicator to measure the implementation of banking intermediation, is the ratio of loans to deposits or loans to deposits ratio (LDR) (Haruna, 2011; Buchory, 2006). The higher this ratio is, the better it means that the bank could carry out intermediation function optimally.

The LDR achieved by the BPD to December 2014 is $89,73 \%$ higher than the national banks $(89,42 \%)$, and other groups such as state banks $(83,73 \%)$; foreign exchange 
banks (81.58\%); non-foreign exchange banks (87,81\%); but lower than joint banks $(123,61 \%)$ and foreign owned banks $(140,04 \%)$ (Bank Indonesia, 2014). Although BPD has achieved LDR higher than the other bank groups, but the credit is larger in the consumer sector, so it is less encouraging economic growth in the region. Thus, the implementation of banking intermediation function becomes less optimal. The not optimal implementation of banking intermediation by BPD is thought to include the effect of the Capital Adequacy Ratio (CAR), Operating Expense to Operating Income Ratio (OEOI), and Non Performing Loan (NPLs).

Based on the phenomenon above, the problem in this research can be formulated into a research question: How the CAR, OEOI, and NPLinfluence the banking intermediation? This study aims to analyze the factors that affect the banking intermediation that allegedly include the effect of the CAR, OEOI, and NPLs.

\section{LITERATURE REVIEW}

2.1. Definition and factors of affecting banking intermediation

Bank is a financial institution whose main activity is receiving public deposits. The funds will be disbursed in the form of loans to communities who need them. Besides taking deposits and giving loans, banks also provide other financial services.

According to the Law No. 7 of 1992 and amended by Law No. 10 of 1998 about Banking, banks are business entities that raise funds from the public in the form of savings and channel them to the public in the form of loans or other forms in order to improve the living standard of the people. The core activities of a bank as a financial institution that are always associated with the transactions or financial activity that occurred in the community are:

1 intermediation (taking deposits and lending money)

2 disintermediation (relinquishing the intermediary

debtor/creditor position, while retaining a 'broker' role)

3 collection and payment system, money transmission

4 foreign exchange, foreign trade services

5 participation in the money and capital market (Cade, 1997)

In simple terms the role of banks in the economy is

to fulfil the desire of ultimate borrowers and the ultimate lenders. However, the role of banks is actually quite complex because there are two interests beside other interests that must be met by a bank and that are those of the owners and the government (regulator). Thus, a bank must be able to balance the various interests (ultimate borrowers, ultimate lenders, owners and regulators) that are sometimes different (Hempel et al., 1994). Given that the banking sector is the intermediary between the parties that have the excess funds and those who need the funds, the reallocation of public funds has important implications for the movement of the economy as a whole. Therefore, the role of banks in the economy is especially from the extent to which the bank can apply its intermediary functions. Financial intermediation is the process of buying funds from surplus economic units (business sectors, government and individual/household) to be distributed to deficit economic units (Hempel et al., 1994). The same is stated by Kidwell and Petterson (2000) which states that intermediation is the process of transformation or direct purchases of a claim with a series of characteristics (maturity, denomination) of DSUs and turn it into a claim indirectly by a different set of characteristics to be sold to SSUs. Meanwhile, according to Gardner (2000), intermediation is a process of transformationfrom secondary securities into primary securities. Primary securities are the claim of individuals, government and non-financial companies, while the secondary securities are claims against financial institutions.

The implementation of financial intermediation in banking can be seen from the bank's ability to transform savings received primarily from household economic units into credit or loans for companies and others to invest in buildings, equipment and other capital goods (Rose, 2002). The indicators commonly used to measure the extent of intermediation by the banking system has been implemented, namely by looking at the ratio of loans to deposits known as Loans to Deposits Ratio (LDR). An indicator to measure the workings of the banking intermediation function is to look at the Loan to Deposit Ratio (LDR). According Buchory (2006), LDR ratio reflects the ability of banks to extend credit and collect public funds. The higher this ratio is, the better it means that the bank could carry out intermediation function optimally. Vice versa, the lower this ratio means the bank in carrying out its intermediary function is not optimal. Some of the causes have not been optimal implementation of banking intermediation in the region, according to research by Bank Indonesia is caused by: the limited authority of the bank branches in deciding loans, the effect of the financial condition of the internal branch of the credit, the existence of alternative investment of funds, the business climate in the region, the precautionary principle (Abdullah and Suseno, 2003).In this study, the authors estimates that not the optimal implementation of the intermediary function (LDR) by BPD (regional development bank) is caused by the following factors : capital (CAR), operational efficiency (OEOI), and credit risk (NPLs).

\subsubsection{Loan to deposit ratio $(L D R)$}

As noted above that the LDR is an indicator in the measurement of banking intermediation. According to the research result Buchory (2006) implementation of financial intermediation function give effect to banking performance. This means that banks will have good financial performance if the bank could apply its intermediary function optimally.For banks in Indonesia, according to Bank Indonesia Circular Letter No. 13/24/DPNP dated October $25^{\text {th }}, 2011$ Subject : Valuation of Level Commercial Bank Soundness and the circular letter No.15/41 / DKMP Jakarta, October $1^{\text {st }}, 2013$ Subject: Calculation of Minimum statutory ReservedDemand Deposit and Compulsory Demand deposit by Loan to Deposit Ratio in Rupiah. Loan to Deposit Ratio hereinafter referred to as the LDR is the ratio of loans to third parties in exchange Rupiah and foreign currancy, excluding loans to other banks, the deposits which include demand deposits, savings and time deposits in Rupiah and foreign currencies, excluding interbank funds. Therefore, a bank's LDR is determined by the bank's ability to collect and distribute funds to third parties in the form of credit. The higher the LDR showed greater use of bank deposits for lending, which means bankhas been capable to run 
intermediary function properly. However, if the LDR is too high can also risea liquidity risk for banks.The implementation of financial intermediation gives effect to banking performance. This means that banks will have good financial performance if the bank apply its intermediary function optimally.

\subsubsection{Theeffect of CAR of the LDR}

Intermediation function can be implemented optimaly if supported by adequate capital (Buchory, 2006). Even though the funds collected by the third party is very large, but if not offset by additional capital the banks will be limited in extending credit. Bank capital is not only important as a source of funds to meet the needs of the bank, but the bank's capital will affect management decisions in the creation of the rate of profit on the one hand and the potential risks on the other.If the bank's strong capital the bank has a strong financial. Under these conditions, the role of capital for banks is very important both as a buffer to accommodate the increased unexpected losses derived from credit, interest rate, liquidity and operational risk as well in order to build public trust. Capital plays a very important role (Culp, 2001), namely as:

1 buffer loss (capital loss as a buffer)

2 investment Mechanism (capital as an investment mechanism).

The same opinion was expressed that the role of capital in the bank are:

1 as a tool for achieving the optimal capital structure (capital as a means for achieving the optimum capital structure)

2 as security guards bank risk management in order to secure (capital a ssubtitute risk management for banks toensure safety) (Schroeck, 2002).

Similarly, according to Rose (2002) that the bank capital plays a very important role in supporting the bank's operations and viability in the long term for bank. The strength of a bank's capital can be measured by the minimum capital adequacy ratio or the the CAR. CAR is an indicator of the ability of banks to provide funds for expansion and accepting risk loss caused by the operations of the bank.For banks in Indonesia, according PBI. 14/18/PBI/2012 November $28^{\text {th }} 2012$ subject : Minimum Capital Adequacy shall be at the low as follows:

a. $8 \%$ of the Risk Weighted Assets (RWA) for the Bank's risk profile rating of 1

b. $9 \%$ to less than $10 \%$ of the RWA for the risk profile of the Bank with a rating of 2

c. $10 \%$ to less than $11 \%$ of RWA for the risk profile of the Bank with a rating of 3

d. $11 \%$ to $14 \%$ of RWA for the risk profile of the Bank with a rating of 4 or 5

The higher the CAR, the greater the financial resources that are able to be used to support implementation of the particular credit intermediation function. According to Soedarto (2004) and by Budiawan (2008), CAR has a positive and significant impact on bank credit. And according to Buchory (2006) implementation of financial intermediation influence on the capital structure of the bank. This means that the bank in carrying out the functions of financial intermediation, especially in lending is needed an additional funds from the public and supported by adequate capital. Nasirudin (2005) research results showed that the level of capital adequacy significant effect on LDR in Central Java. Then, according Siringoringo (2012) capital structure simultaneously affect the intermediation function Bank. Furthermore, research results Tangko (2012) showed that the variables CAR significantly influence to LDR.Similarly,the result research of Sitorus (2013) entitled Analysis of Factors influence of Non -Performing Loans (NPLs) at Go Public Bank at Indonesia Stock Exchange period 2005-2011, the result of the research indicates that the Capital Adequacy Ratio (CAR), influence the Loan to Deposit Ratio (LDR) . While the study results Mbizi (2012), entitled An Analysis of the Impact of Minimum Capital Requirements on Commercial Bank Performance in Zimbabwe, findings revealed that there is a significant and positive relationship between commercial bank capitalization and its performance. Utari research results and Haryanto (2011) the results showed that CAR is not significant positive influence on the LDR with a significance level of $0.192>0.050$.And the results of Tamtomo research (2012) partially Capital Ratio Adequacy positive and significant effect on LDR.

\subsubsection{The effect of $O E O I$ of $L D R$}

Profitability ratios used to analyze or measure the level of business efficiency and profitability achieved by the bank itself. One of a profitability ratio is ratio of Operating Expenses to Operating Income (OEOI) in the same period. OEOI ratio is also often used as an indicator to measure the level of efficiency of a bank. Circular Letter of Bank Indonesia No. On 06/23/2005 Rating System for Commercial Banks set ROA ratio ranged from $94 \%$ to $96 \%$ with the criteria quite well. If the ratio of a bank that achieved the figure below the level of efficiency is good. And vice versa, the lower level of OEOI ratio means the better performance of the bank's management in using its resources or the lower the OEOI ratio achieved by the bank, the more efficient the bank. Asset-liability management of efficient banks will improve the profitability of the bank. And high profitability is one of the sources of bank capital to improve the intermediation function. The result of research Utari and Haryanto (2011) found that OEOI has a significant positive effect on the LDR with a significance level of 0.001 $<0.050$. Similarly, the research results of Wiagustini and Oktaviantari (2012), Ratio of Operating Expenses to Operating Income (OEOI) but no significant negative effect on the Loan to Deposit Ratio (LDR). Research results in line with previous research conducted by Amriani (2012) who found the results OEOI statistically no significant effect on LDR. Similarly, research conducted by the Granita (2011) who found that OEOI negative but insignificant effect on LDR, and research results of Sitorus (2013) indicates that the Operational Cost of Operational Income (OEOI) influence the Loan to Deposit Ratio (LDR).

\subsubsection{The effect of NPLs of the LDR}

Credit is the greatest asset investment banks. Similarly, loan interest income is the largest source of revenue for banks. If the credit returns fail then the ability of banks to provide new loans will be disrupted. In addition to the bank's 
revenue would also decrease in interest income due to nonreceipt of credit. Besides, the bank also must establish reserves or provisions of problem loans that ultimately will reduce the bank's capital. Though, much capital is needed for credit expansion. The reduced of banks ability to provide credit to interfere with the implementation of the bank intermediation. Credit quality of a bank is indicated by the NPL. Thus, NPL can be used to measure the ability of banks to cover the risk of default of loan repayment by the debtor. Based on Bank Indonesia Circular Letter No. 13/24/DPNP on October 25th, 2011 concerning the Commercial Banks, problem loans are loans to a third party of non bank consist of non performing loan (sub standard), doubtful and loss. The higher the level of NPLs, the greater the credit risk borne by the bank. NPL rate may affect the level of efficiency of banks. The research Karim, Chan and Hassan (2010) states in Malaysia and Singapore, clearly indicate thathigher non-performing loan reduces cost efficiency. Therefore, banks should be able to press a low NPL ratio so that the potential benefits to be gained will be even greater, because banks will save the allowance for credit losses Allowance for troubled or Assets (PPAP). The low Allowance (PPAP) formed the greater profitability and ultimately improve the bank's capital. According to Sentausa (2009) cited by Pratama (2010), the amount of NPLs to be one of the causes of the difficulty banks in lending. Similarly, according to Harmanta and Ekananda (2005) NPL is significantly and negatively related to bank credit. Therefore, according to Budiawan (2008) NPL has effect negatively and significant on bank credit. Meanwhile, according to Soedarto (2004), NPLs effect positively and significant on bank credit. While the study results of Nasirudin (2005) showed that the variable NPLs have asignificant effect on LDR. The research results of Utari and Haryanto (2011) showed that NPL has a significant negative influence on the LDR with a significance level of $0.000<0.050$. The same thing was stated Tamtomo (2012) and Tangko (2012) that NPL variable effect negatively and significant on LDR. Meanwhile, according to Al-Abedallat and Al-Shubiri (2013) research has empirically examined the determinants of credit risk held by Jordanian banks over the 2006 to 2010 periods The credit risk is one of the main risks that seriously affect banks' stability. Meanwhile, according to Sitorus (2013) the result of the research indicates that the CAR, ROA, NIM and OEOI that totally influence the NPL.

\subsection{Hypothesis}

Based on the relationship between research objectives and theoretical framework to the formulation of the research problem, the hypothesis are as follows:

H1: CAR positively effect on LDR

H2: OEOI positively effect on LDR

H3: NPL negatively effect on LDR

H4: CAR, OEOI, and NPL effect on LDR

\section{RESEARCH METHOD}

3.1. Research method

The methods used in this research are descriptive method and verification method. Descriptive method is a method used to analyze data in a way to describe or depict the data that has been collected as is without intending to apply general conclusions or generalizations while the verification method is a method of research that aims to determine the relationship between two or more variables. This verification method is used to test the truth of a hypothesis. Influence or shape the causal relationship between variables $\mathrm{X}$ and $\mathrm{Y}$ can be known from the research method of verification. (Sugiyono, 2009)

3.2. Type,data source, population, sample and data collection methods.

Data used in this study is secondary data All Indonesian regional development banks which include CAR, OEOI, NPLs, and the LDR were obtained from the Indonesian Banking Statistics and Data Center Consultant EKOFIN Publications in 2014 (calculated quarterly). The research population was 26 regional development banks (BPD) serve as the object of study. While the object is observed financial statements position December 31st, 2014. Data collection method used was to study the documentation. Study of documentation is done with the data collection and classification category of written materials related to the research problem.

\subsection{Operational Variables}

This study uses the independent variables, namely CAR, OEOI, and NPLs and the dependent variable is the implementation of function banking intermediation as measured by the LDR.

\subsection{Analysis Techniques Data}

The data analysis technique used in this study is a multiple linear regression. First, it is tested to determine whether the assumptions of classical linear regression model doesn't have problem of normality, multi-collinearity, heterocedastity and autocorrelation. If all of them were fulfilled means that the model has a decent analysis used (Gujarati, 2003). To examine the hypothesis was used T-test to determine statistical significance of the effect of independent variables on the dependent variable partialy, F-test to determine the statistical significance of the coefficient of multiple significance or F-test to determine significance of the independent variables on the dependent variable simultaneously. Data processing is done by using the software Statistical Package for Social Science (SPSS) version 20.0 for Windows. The regression equation used is as follows:

Where,

$$
\mathrm{Y}=a+\beta X_{1}+\beta X_{2}+\beta X_{3}+\mathrm{e}
$$

$\mathrm{Y}=\mathrm{LDR}$

$\mathrm{a}=\mathrm{A}$ constant which is the value of the variable $\mathrm{Y}$ when the variable $\mathrm{X}$ is 0 (zero)

$\beta=$ Coefficient of the regression line

$\mathrm{X}_{1}=\mathrm{CAR}$

$\mathrm{X}_{2}=$ OEOI

$\mathrm{X}_{3}=$ NPLs

$\mathrm{e}=$ Residual

\section{RESULT AND DISCUSSION}

4.1. The development LDR, CAR, OEOI, and NPLs regional development bank in Indonesia

Based on data until December 2014, the development of LDR, CAR,OEOI and NPLs were achieved by 26 regional 
development banks operating in Indonesia (see Table 1) can be described as follows:

The average value of LDR achieved by BPD until December 31, 2014 amounted to $89.73 \%$. That is BPD throughoutIndonesia have been able to apply the functions of bank intermediation through fund raising and lending of $89.73 \%$, higher than the national banks $(89.42 \%)$, and other groups such as state banks $(83.73 \%)$; foreign exchange banks (81.58\%); non-foreign exchange banks $(87,81 \%)$; but lower than joint banks $(123,61 \%)$ and foreign owned banks $(140,04 \%)$ (Indonesian Banking Statistics, 2014). The lowest value of LDR at $73.80 \%$ is achieved by BPD South East Sulawesi, while the highest value of LDR at $120.44 \%$ is achieved by BPD South Sulawesi. The average value of CAR achieved until the period December 31, 2014 amounted to $19.13 \%$ is above the minimum capital requirement of $8 \%$ as required by Bank Indonesia. The highest CAR at $29.15 \%$ was achieved by BPD Central Kalimantan and the lowest CAR at $14.17 \%$ was achieved by BPD Central Java. Therefore, the average value of the CAR indicates that $\mathrm{BPD}$ still has the capital ability to increase intermediation function through lending distribution.

The average value achieved OEOI period December 31, 2014 amounted to $75.31 \%$. The highest value of $99.56 \%$ OEOI achieved by BPD Maluku and the lowest OEOI amounted to $61.07 \%$ achieved by the BPD Central Kalimantan. By looking at the average value of OEOI is still below the tolerance required by Bank Indonesia at $94 \%$ $96 \%$. This means that BPD is able to control its operational efficiency so that the BPD still has the ability to improve the function of intermediation through lending.

The average NPLs value was $2.70 \%$ achieved by period of December 31, 2014. The highest NPL value of $10.36 \%$ was achieved by BPD East Kalimantan and the lowest NPLs was $0.35 \%$ achieved by BPD Bali. By looking at the average value of the NPL shows that the credit risk was faced by BPD are at moderate albeit under tolerance required by Bank Indonesia at $3 \%-6 \%$. It means being able to control the risk of BPD lending. Because if NPLs increase will disrupt the BPD's ability to improve the function of intermediation through lending.

TABLE 1

The Development of the LDR, OEOI, NPL, and ROA of BPDs in Indonesia by December 31, 2014 (Percentage)

\begin{tabular}{|c|c|c|c|c|c|}
\hline No. & BPDs & LDR & CAR & OEOI & NPLs \\
\hline 1 & DI-Aceh & 92.38 & 17.79 & 74.11 & 2.58 \\
\hline 2 & North Sumatera & 95.89 & 14.38 & 80.30 & 5.47 \\
\hline 3 & West Sumatera & 98.34 & 15.76 & 84.51 & 2.52 \\
\hline 4 & South Sumatera & 85.97 & 16.82 & 81.54 & 7.10 \\
\hline 5 & Bengkulu & 86.06 & 17.25 & 72.41 & 0.39 \\
\hline 6 & Lampung & 112.96 & 18.87 & 69.33 & 1.06 \\
\hline 7 & Riau & 77.72 & 18.27 & 70.59 & 2.79 \\
\hline 8 & Jambi & 100.83 & 27.11 & 71.45 & 0.48 \\
\hline 9 & DKI-Jakarta & 92.57 & 17.96 & 80.26 & 4.38 \\
\hline 10 & West Java & 93.18 & 16.08 & 85.94 & 4.15 \\
\hline 11 & Central Java & 88.57 & 14.17 & 75.67 & 0.93 \\
\hline 12 & DIY-Jogyakarta & 80.34 & 16.60 & 72.64 & 0.87 \\
\hline 13 & East Java & 86.54 & 22.17 & 69.63 & 3.31 \\
\hline 14 & West Kalimantan & 87.09 & 19.21 & 71.77 & 0.48 \\
\hline 15 & East Kalimantan & 78.54 & 18.11 & 80.39 & 10.36 \\
\hline 16 & Central Kalimantan & 79.82 & 29.15 & 61.07 & 0.82 \\
\hline 17 & South Kalimantan & 91.44 & 21.12 & 75.15 & 3.86 \\
\hline 18 & North Sulawesi & 90.10 & 14.28 & 83.70 & 1.29 \\
\hline 19 & South Sulawesi & 120.44 & 25.16 & 69.27 & 1.40 \\
\hline 20 & Central Sulawesi & 111.84 & 23.83 & 71.67 & 2.86 \\
\hline 21 & Southeast Sulawesi & 73.80 & 22.17 & 60.89 & 1.04 \\
\hline 22 & Bali & 96.41 & 20.17 & 64.89 & 0.35 \\
\hline 23 & West Nusa Tenggara & 99.78 & 19.34 & 66.00 & 1.46 \\
\hline 24 & East Nusa Tenggara & 87.69 & 18.00 & 73.83 & 1.43 \\
\hline 25 & Maluku & 92.26 & 17.34 & 99.56 & 2.38 \\
\hline \multirow[t]{4}{*}{26} & Papua & 80.12 & 16.28 & 91.38 & 7.38 \\
\hline & Minimum & 73.80 & 14.17 & 61.07 & 0.35 \\
\hline & Maximum & 120.44 & 29.15 & 99.56 & 10.36 \\
\hline & Average & 89.73 & 19.13 & 75.31 & 2.70 \\
\hline
\end{tabular}

Source: Published Financial Statements, December 31,2014, downloaded May,39, 2015, processed.

\subsection{Multiple linear regression analysis}

Multiple linear regression analysis was used to determine basically dependence of dependent variable with one or more independent variables, with the aim of estimating or predicting the average of population data or average value of the dependent variable based on the value of the independent variable known (Gujarati, 2003). By regression analysis it can be seen whether there is influence between independent variables with the dependent variable. The results of multiple linear regression analysis in this study can be seen in Table 2. 

follows :

Based on Table 2, the regression equation is as

$$
L D R=0.506+0.916 \mathrm{X}_{1}+0.359 \mathrm{X}_{2}-0.132 \mathrm{X}_{3}
$$

The equation above it can be explained as follows:

1. Constant value (a) of 0.506 , which means a positive constant value. This shows if the CAR $\left(\mathrm{X}_{1}\right)$, OEOI $\left(\mathrm{X}_{2}\right)$, and NPLs $\left(\mathrm{X}_{3}\right)$, has a value of zero, then the LDR (Y) increase by 0.506

2. Regression coefficient for the variable $\mathrm{CAR}\left(\mathrm{X}_{1}\right)$ is 0.916 , indicating the direction of the relationship between CAR $\left(\mathrm{X}_{1}\right)$ with LDR $(\mathrm{Y})$, meaning that if the addition of CAR $\left(\mathrm{X}_{1}\right)$ for every one unit, assuming other variables constant, the LDR (Y) increase by 0.916 . And vice versa, if there is a reduction of CAR $\left(\mathrm{X}_{1}\right)$ of the unit it will decreasethe LDR (Y) equal to 0.916.

3. Regression coefficient for the variable $\operatorname{OEOI}\left(\mathrm{X}_{2}\right)$ is 0.359 , indicating the direction of the relationship between $\operatorname{OEOI}\left(\mathrm{X}_{2}\right)$ with $\operatorname{LDR}(\mathrm{Y})$, meaning that if there is additional $\mathrm{OEOI}\left(\mathrm{X}_{2}\right)$ per unit, assuming other variables remain it will increase the LDR (Y) amounted to 0.359. And vice versa if there is a reduction in OEOI $\left(\mathrm{X}_{2}\right)$ of one unit will reduce the LDR (Y) equal to 0.359 .

4. Regression coefficient for the variable $\operatorname{NPLs}\left(\mathrm{X}_{3}\right)$ is 0.132 , indicating a negative relationship between the NPLs $\left(\mathrm{X}_{3}\right)$ with $\operatorname{LDR}(\mathrm{Y})$, meaning that if there is additional NPLs $\left(\mathrm{X}_{3}\right)$ per unit, assuming other variables remain the LDR (Y) was reduced by 0.132 . And vice versa if there is a reduction in NPL $\left(\mathrm{X}_{3}\right)$ of the unit it will increase the LDR (Y) equal to 0.132 .

Table 2. Test results of multiple linear regression coefficients ${ }^{\mathrm{a}}$

\begin{tabular}{|c|c|c|c|c|c|c|}
\hline & \multirow{2}{*}{ Model } & \multicolumn{2}{|c|}{$\begin{array}{l}\text { Unstandardized } \\
\text { Coefficients }\end{array}$} & \multirow{2}{*}{$\begin{array}{c}\text { Standardized } \\
\text { Coefficients }\end{array}$} & \multirow{2}{*}{$\mathrm{t}$} & \multirow{2}{*}{ Sig. } \\
\hline & & B & $\begin{array}{l}\text { Std. } \\
\text { Error }\end{array}$ & & & \\
\hline \multirow{4}{*}{1} & (Constant) & .506 & .165 & & 3.070 & .003 \\
\hline & CAR & .916 & .343 & .314 & 2.673 & .009 \\
\hline & OEOI & .359 & .162 & .287 & 2.210 & 029 \\
\hline & NPLs & -.132 & .048 & -.299 & $2.780^{-}$ & .007 \\
\hline
\end{tabular}

a. Dependent Variable: LDR

Source: Output SPSS 20.0

\subsection{Analysis of correlation coefficient and coefficient of determination}

Correlation coefficient analysis was used to determine the direction and the strong relationship among the three independent variables. Those are the variable CAR $\left(\mathrm{X}_{1}\right)$, OEOI $\left(\mathrm{X}_{2}\right)$, and NPLs $\left(\mathrm{X}_{3}\right)$ with LDR as a dependent variable (Y). (see table 3).Based on Table 3, it can be concluded that the variable the CAR $\left(\mathrm{X}_{1}\right)$, OEOI $\left(\mathrm{X}_{2}\right)$, and NPLs $\left(\mathrm{X}_{3}\right)$ with LDR dependent variable has a value of correlation (r) 0.358, meaning that the correlation (relationship level) the CAR $\left(\mathrm{X}_{1}\right)$, OEOI $\left(\mathrm{X}_{2}\right)$, and NPLs $\left(\mathrm{X}_{3}\right)$ with LDR dependent variable $(\mathrm{Y})$ are in low correlation (Sugiyono, 2009). While the coefficient of determination analysis was used to determine the contribution effect of CAR $\left(\mathrm{X}_{1}\right)$, OEOI $\left(\mathrm{X}_{2}\right)$, and NPLs $\left(\mathrm{X}_{3}\right)$ with LDR dependent variable $(\mathrm{Y})$ as a dependent variable
(Y) expressed as a percentage. Analysis of the coefficient of determination is squaring the correlation value $\left(\mathrm{R}^{2}\right)$ and based on Table 3 that the $\mathrm{R}^{2}$ value was 0.128 .So when multiplied by $100 \%$, the contribution or effect of variable CAR $\left(X_{1}\right)$, OEOI $\left(\mathrm{X}_{2}\right)$, and NPLs $\left(\mathrm{X}_{3}\right)$ with LDR dependent variable $(\mathrm{Y})$ is $12.8 \%$ indicating that CAR $\left(\mathrm{X}_{1}\right)$, OEOI $\left(\mathrm{X}_{2}\right)$, and $\operatorname{NPLs}\left(\mathrm{X}_{3}\right)$, accounted for $12.8 \%$ of the LDR (Y), while the remaining $87.2 \%$ thought to be influenced by other variables not examined.

Table 3.Test results correlation coefficient and coefficient of determinationmodel summary ${ }^{b}$

\begin{tabular}{|l|r|r|r|r|}
\hline Model & R & R Square & $\begin{array}{r}\text { Adjusted } \\
\text { R Square }\end{array}$ & Std. Error of the Estimate \\
\hline 1 & $.358^{\mathrm{a}}$ & .128 & .102 & .1048731 \\
\hline
\end{tabular}

b. Predictors: (Constant), BOPO, NPL, CAR

Source : Output SPSS 20.0

\subsection{Partial significance test (t-test)}

To examine hypotheses on the significance of the partial model used t-test. It is intended to determine the effect of independent variables (CAR, OEOI and NPLs) partially to the dependent variable (LDR). Partially, the influence of the three independent variables to the LDR as an independent variables, shown in the Table 4 partial test results (t-test), it can be argued that:

\section{Effect of CAR on the LDR}

Partial test results between the CAR with an LDR shows the t-test value of 2.673 is greater than t-table (2.074) with a significant value of 0.009 which is below 0.05 . This means that the CAR effects on LDR and significant. Thus hypothesis H1 stating CAR positively effect on LDR is acceptable.The test results are in line with previous research conducted by Soedarto (2004); Nasirudin (2005); Buchory (2006); Budiawan (2008); Tangko (2012); Tamtomo (2012); Mbizi (2012) and Sitorus (2013) which states that CAR has positive and significant effect as an indicator on the implementation of banking intermediation function. However, contrary to the results of researchUtari and Haryanto (2011) which states that CAR does not have significant positive effect on the LDR with a significance level of $0.192>0.050$.

2. Effect of OEOI on the LDR

Partial test results between the OEOI to LDR shows the $\mathrm{t}$-test value of 2.273 is greater than t-table (2.074) with a significant value of 0.029 which was below 0.05 . This means that the OEOI effects on LDR and significant. Thus hypothesis $\mathrm{H} 2$ which states OEOI positively effect on LDR is acceptable. The test results are in line with previous research conducted by Sitorus (2013) which states indicates that the Operational Cost of Operational Earnings (OCOE) influence the Loan to Deposit Ratio (LDR). While the research conducted by the Granita (2011); Oktaviantari and Wiagustini (2012) found that the ratio of Operating Expenses to Operating Income (OEOI) negative effect but no significant on the Loan to Deposit Ratio (LDR). Yet the results of this test are not in line with the results of the study Utari and Haryanto (2011) the OEOI results has a significant positive effect 
on the LDR with a significance level of $0.001<0.050$. While the results of research conducted by Amriani (2012) found that OEOI results was not statistically significant effect on LDR

\section{Effect of NPLs on the LDR}

Partial test results between NPLs to LDR shows the ttest value of -2.780 less than the t-table (2.074) with a significant value of 0.47 which is below 0.07 . This means that the NPLs effect on LDR and significant. Thus the hypothesis H3 which states NPL negatively effect the LDR, is acceptable. This mean NPLs in BPD have a significant impact on the implementation of banking intermediation. The test results are in line with the previous research results of Pratama (2010), Harmanta and Ekananda (2005), Nasirudin (2005), Utari and Haryanto (2011), Tamtomo (2012) and Tangko (2012) that partially, NPLs variable has negative effect and significant to the LDR.However, in contrast to previous research conducted Soedarto (2004) that states NPLs positive and significant effect on bank credit. Meanwhile, according to Budiawan (2008) which states that NPL no significant and negative effect on bank credit.

Table 4. Partial test results (t-test)

\begin{tabular}{|c|c|c|c|c|}
\hline Model & t-count & t-table & Sig & Description \\
\hline (Constant) & 3.070 & & .000 & \\
\hline CAR & 2.673 & 2.074 & .009 & Significant \\
\hline OEOI & 2.273 & 2.074 & 029 & Significant \\
\hline NPLs & -2.780 & 2.074 & .007 & Significant \\
\hline
\end{tabular}

a. Dependent Variable: LDR

Sumber : Output SPSS 20.0

\subsection{Simultaneous significant test (F-test)}

F - test was conducted to determine the effect of independent variables (CAR,OEOI, and NPLs) simultaneously to the dependent variable (LDR). Simultaneous influence of the four independent variables to the independent variables LDR is shown in Table 5. Based on the results of the F-test calculations in Table 5, F-count was4.898 larger than the F-table (2.840) with a significance value (sig) of 0.003 is below than 0.05 . This means that the independent variables (CAR, OEOI, and NPLs) simultaneously significant effect to dependent variable (LDR). Thus the H4 hypothesis which states CAR, OEOI, and NPLs effect on LDR is acceptable. The test results are in line with previous research conducted by Prayudi (2011) that the variable CAR, NPL, OEOI, ROA and NIM with the F test, simultaneouslyaffect the LDR. Furthermore, according to Siringoringo (2012) research results, that is simultaneously affect the capital structure of the Bank intermediation function. And Tangko (2012) research results, showed that the variables CAR and NPL have significantly influence on LDR, and NPL variable has a significant negative effect on LDR. Similarly, the results of research Sitorus (2013) which states that the CAR, ROA, NIM and OEOI influence the LDR.Nasirudin (2005) states that CAR and NPL have a significant effect on LDR. While Tamtomo (2012) found that during the research period partially, variable of CAR and ROA ratio is positive and significant effect on LDR of a company, NPLs has negative effect and significant on LDR of a company, while the third party funds no effect on LDR of a company. The research results showed that the CAR variables significantly influence to LDR and NPL variable and has a significant negative effect on LDR. But according to Utari and Haryanto (2011), the results showed that the five independent variables (CAR, NPL, ROA, OEOI and GWM) influence by $24.4 \%$ against the level of liquidity proxy LD, .and the CAR does not have significant positive influence on the LDR with a significance level of $0.192>0.050$, NPL has a significant negative influence on the LDR with a significance level of $0.000<$ 0.050. ROA does not significant negative influence on the LDR with a significance level of $0.560>0.050$, and OEOI has a significant positive effect on the LDR with a significance level of $0.001<0.050$.

Tabel 5. Simultaneous test results (F-test)

\begin{tabular}{|c|c|c|c|c|c|}
\hline \multicolumn{6}{|c|}{ ANOVA $^{a}$} \\
\hline Model & $\begin{array}{l}\text { Sum of } \\
\text { Squares }\end{array}$ & df & $\begin{array}{c}\text { Mean } \\
\text { Square }\end{array}$ & F & Sig. \\
\hline $\begin{array}{ll} & \text { Regression } \\
1 & \text { Residual } \\
& \text { Total }\end{array}$ & $\begin{array}{r}.162 \\
1.100 \\
1.261\end{array}$ & $\begin{array}{r}3 \\
100 \\
103\end{array}$ & $\begin{array}{l}.054 \\
.011\end{array}$ & 4.898 & $.000^{\mathrm{b}}$ \\
\hline
\end{tabular}

a. Dependent Variable: LDR

b. Predictors: (Constant), CAR, NPLs, OEOI

\section{CONCLUSION}

Based on the background, the formulation of the problem, hypotheses, methods and research results and discussion, some conclusions can be drawn as follows:

1. In 2012 BPD (Regional Development Bank) throughout Indonesia are able to carry out banking intermediation function as measured by the Loan to Deposit Ratio (LDR) of $89.73 \%$, higher than the national banks and other banks, but still within the range of the LDR is determined by Bank Indonesia. Lowest LDR value reached by the BPD South East Sulawesi, while the highest LDR value achieved by the BPD South Sulawesi.

2. Based on the test results partially that variable of CAR and OEOI have positive and significant effects on LDR. While the NPLs has negativeand significant effect on LDR.

3. Based on the test results simultaneously that variable of CAR, OEOI, and NPLs significantly effect on LDR with level of influence of $12.8 \%$, while the remaining $87.2 \%$ influenced by other factors not examined in this study

\section{REFERENCES}

Abdullah, Piter and Suseno (2003), Regional Banking Intermediation Function : Measurement and Identification, Bulletin of Monetary Economics and Banking, Bank Indonesia, Volume 5 Nomor 4, Maret 2003. P 43 - 63 .

Al-Abedallat, A. Z., \& Al-Shubiri, F. N. (2013). Analysis the determinants of credit risk in Jordanian banking: An 
empirical study. Journal Management Research and Practice, 5(3), 21-30.

Amriani, R. F. (2012). Analysis of the effect of CAR, NPL, ROA, and NIM against LDR on state-owned bank in Indonesia period 2006-2010. Thesis. Management Department Faculty of Business and Economic, Hasanuddin University, Makasar.

Astohar (2012). The Role of Net Interest Margin (NIM) in Strengthen Effect on the Loan to Deposit Ratio (LDR) of changes in Earnings On a Devisa Bank Registered in Indonesian Bank 2006-2009. Economic Focus Journal, STIE (Economic School) Pelita Nusantara Semarang, Edition No. 1 Volume 7, June 2012, ISSN 19076304. P $30-42$.

Bank Indonesia. (2012). Bank Indonesia Regulation (PBI) No. 14/18/PBI/2012. November 28, subject : The minimum capital adequacy of commercial banks for Commercial Banks Headquartered in Indonesia.

Bank Indonesia. (2013). Bank Indonesia Circular letter (SE) No. 15/41/DKMP. October 1, subject: Calculation of minimum statutory reserved demand deposit and compulsory demand deposit by loan to deposit ratio in rupiah for Commercial Banks Headquartered in Indonesia. Please add the publish place.

Bank Indonesia. (2011). Bank Indonesia Circular letter (SE) No. 13/24/DPNP. October 25, subject: Valuation of level commercial bank soundness for Commercial Banks Headquartered in Indonesia.

Bank Indonesia, 2014. Indonesian Banking Statistics, Volume 13, No. 1, December, 2014, ISSN-2086-2954.

Bank Indonesia. (2013). Publication of banking financial statement. Retrieved from http://www.bi.go.id

Buchory, H. A. (2006). The influence of financial intermediary function implementation, risk management application and bank capital structure on banking financial performance. Disertasion, Faculty of Economic, Padjadjaran University, Bandung.

Buchory, H. A. (2014). Analysis of factors affecting implementation of banking intermediation function: Study on regional development bank all over Indonesia in 2012. Proceedings from SIBR 2014 Conference on Interdisciplinary Business and Economics Research. February 7-8, Kuala Lumpur, Malaysia.

Budiawan. (2008). Analysis of factors affecting the distribution of credit in rural bank (BPR): Case study at Bank Indonesia Banjarmasin. Thesis. Magister Management Study Program of Diponegoro University Semarang.

Budiwiyono, E. (2012). BPD (regional development bank) for strength in accelerating implementation of regional autonomy: Prospects and problems. Proceedings fromthe National Seminar on Indonesian Economist Association, Yogjakarta, October, 02 - 04, 2012.

Cade, E. (1997). Managing banking risk. Cambridge, London: Gresham Books.

Culp, C. L. (2001).The risk management process: Business strategy and tactics. New York: John Willey \& Sons, Inc.

Financial Service Authorithy Republic of Indonesia, 2014

Gardner, M. J., Mills, D. L., \& Cooperman, E. S. (2000). Managing financial institutions: An assets/liability approach. New York: Dryden Press.

Graddy, D. B., Spencer, A., \& Brunsen, W. H. (1985).Commercial banking and the financial services industry. Virginia: Reston Publishing Company Inc., A Prentice-Hall Company.

Granita, J. K. (2011). Influence analysis of deposits, CAR, ROA, NPL, NIM, BOPO, interest rates, inflation and exchange rate against LDR (studies in national private exchange bank 2002-2009 period). Thesis in Bachelor Program Economic Faculty Diponegoro University, Semarang.

Gujarati, D. (2003). Basic econometric (4th ed.). New York: Mc. Graw-Hill Book Co.

Harmanta, \& Ekananda, M. (2005). Disintermediation function post-crisis banking in Indonesia 1997: Factor of demand or supply loans, a model approach to disequilibrium.Bulletin of Monetary Economics and Banking, 8(1), 51-78.

Haruna, M. A. (2011). Determinant of cost of financial intermediation in Nigeria's pre-consolidated banking sector. Department of Accounting Ahmadu Bello University, Zaria, Nigeria.

Hempel, G. H., Simonson, D. G., \& Coleman, A. B. (1994). Bank management: Text and cases (4th ed.). New York: John Wiley \& Sons, Inc.

Karim, Mohd Zaini and Sok-Gee Chan (2008). Bank Efficiency and Non Performing Loans in Malaysia and Singapore, Proceeding of Applied International Business Conference, 6-8 November, 2008, Grand Dorsett Hotel, Labuan. P. 948 - 958.

Karo Karo (2013). Ekofin Konsulindo, Banking \& Financial Consultant. Indicators and directory of Indonesian banking in 2012. Jakarta.

Kidwell, D. S., \& Petterson, R. I. (2000). Financial institution, market, and money. New York: Dryden Press.

Koch, T. W. (2000). Bank management. International edition. Orlando: The Dryden Press, Harcourt Brace College Publishers.

Mahran, H. A. (2012). Financial intermediation and economic growth in Saudi Arabia: An empirical analysis, 1968-2010. Journal Modern Economy, 3(5), 626-640.

Mbizi, R. (2012). An analysis of the impact of minimum capital requirements on commercial bank performance in Zimbabwe. International Journal of Independent Research and Studies, 1(4), 124-134.

Ministry of Internal Affair of The Republic Indonesia (1999). Article Number 62 of 1999, Guidelines for Organization and Work of Regional Development Banks

Mishkin, F. S., \& Eakins, S. G. (2006). Financial market \& institutions (5th ed.). New York: Pearson, Addison Wesley.

Nasirudin. (2005). Analysis of factors affecting the loan to deposit ratio (LDR) at rural bank in region job bank Indonesia Semarang. Thesis. Magister Management Study Program of Diponegoro University Semarang.

Oktaviantari, L. P. E., \& Wiagustini, N. L. P. (2012). Effect of banking risk to profitability on rural banks in Badung. Economic Faculty Udayana University, Bali, 
Indonesia.

Pratama, B. A. (2010). Analysis of factors affecting bank lending policy (study on commercial banks in Indonesia period 2005-2009). Thesis. Master Program in Management, Diponegoro University, Semarang.

Prayudi, A. (2011). Pengaruh capital adequacy ratio (CAR), non performing loan (NPL), BOPO, return on asset (ROA) dan net interest margin (NIM) terhadap loan to deposit ratio (LDR). Retrieved from http://www.papers.gunadarma.ac.id/ index.php/mmanagement/article/.../14225

Rose, P. S. (2002). Commercial bank management. Chicago: Richard D. Irwin, Inc.

Rose, P. S., \& Hudgins, S. (2008). Bank management \& financial services (6th ed.). Chicago: McGraw-Hill International Edition.

Schroeck, G. (2002). Risk management and value creation. New Jersey: John Wiley \& Son, Inc.

Sentausa, Sentot A. 2009. Banking Ask Bank Indonesia Easing Rules. Kompas.com. Wednesday, March $25^{\text {th }}$, 2009

Siringoringo, R. (2012). Characteristics and functions of banking intermediation in Indonesia. Bulletin of Monetary Economics and Banking, 15(1), 61-83.

Sitorus, V. Y. (2013). Analysis of factors influence non performing loan (NPL) at go public bank at Indonesia stock exchange period 2005-2011. Retrieved from http://www.sciencegate.ch/

Soedarto, M. (2004). Factor that affects distribution rural credit bank [BPR (rural bank) case study in work area bank Indonesia Semarang]. Thesis. Magister Management Study Program Diponegoro University, Semarang.

Sugiyono. (2009). Research methods. Jakarta: Salemba Empat.

Supriyanto, Eko. B.(2013).Indonesian banking challenges in 2013. Bureau of Research Infobank, Jakarta.

Tamtomo, Handy Setyo, and Hersugondo (2012). Effect of CAR, NPL, ROA Against LDR Indonesia Banking Company, Students' Journal of Accounting and Banking, Stikubank University, Semarang, Volume 1, No. 1, 2012. , Abstract, p. 1

Tangko, I. L. F.(2012). Analysis of effect of capital adequacy ratio (CAR) and non-performing loans (NPL) of the loan to deposit ratio (LDR) in the state-owned bank in Indonesia. Thesis. Management Department, Economic and Business Faculty, Hasanudin University, Makasar.

The Republic Indonesia (1962). Actof the Republic Indonesia number 13 of 1962 on Main Provisions of the Regional Development Banks

The Republic Indonesia (1992). Act of the Republic IndonesiaNumber 7 of 1992 as amended in Act Number 10 of 1998 on Banking

Utari, M. P., \& Haryanto, A. M. (2011). Analysis of effect of CAR, NPL, ROA and BOPO on LDR (case studies in national private exchange bank in Indonesia period 20052008). Undergraduate thesis. Diponegoro University, Semarang.
*Dr. Herry Achmad Buchory,SE,MM.is a Lecturer of EKUITAS Economics College Bandung, Indonesia, last educational degree in the Doctoral field of Economics Padjadjaran University in 2006. Teaching experience in addition to the EKUITAS is a lecturer in the Master of Accounting, Master of Applied Economics and Master Management Program in Padjadjaran University; Master Management Program Islamic University of Bandung and Bandung Widyatama University Master of Management. As banking practitioner,the author worked in PT. Bank Jabar Banten since 1976 with various assignments, the last position before entering full duty was as Director of Compliance and Risk Management.

In the field of organization, the author is active as a board member of Indonesian Economists Association (ISEI) Branch Coordinator Bandung West Java, a member of The Institute of Internal Auditors, members of the Indonesian Bankers Association (IBI), was once the caretaker Banking Compliance Forum Communications Director (FKDKP) and Alumni Association board of Padjadjaran University Commissariat of Bandung, a member of the Expert Council of Economic Forum (FEJ) West Java.

He wrote numerous works published in the Journal of the National and International accredited. Writing books include: The Basics of Marketing Bank (ISBN: 979.97115.5.X year 2006), Introduction to Business (ISBN: 979.97115.8.8I year 2008), Marketing Management (ISBN: 978.602.96449.1.3 Year 2010); Management Strategic (ISBN: 987.60296449.0.6 Year 2010), and the Management of Financial Institutions (ISBN: 978.602.96449.5.1. Year 2011). 